\title{
How Long Can Your Company Go Without Revenue?
}

\author{
Phil Greenwood (University of Wisconsin - Madison)
}

KEYWORDS: Entrepreneurship, start-up finance.

In a recent podcast "Invest Like the Best" (https://podcasts.google.com/feed/aHR0cHM6Ly9pbnZl c3RsaWtldGhlYmVzdC5saWJzeW4uY29tL3Jzcw/epis ode/NGZkOGY5MWMtNjljNC00MmQ2LTg5NzMtZjM4 Y2RmN2/4YmMw?hl=en\&ep=6) by Patrick O'Shaughnessy, the host was interviewing Atreides Management Founder and CIO Gavin Baker on the current investment environment during the Covid-19 crisis. One comment by Baker that caught my attention was that investors are asking companies of all sizes to calculate their "zero revenue solvency rate" (i.e., how long cash will last with zero revenues for an extended length of time).

While this is a radical development for the financial management of a large company (Who would ever think that an existing organization would be reduced to zero revenues in such a short time?), folks who work in the early-stage startup arena recognize that what they are really seeking is "the Cash Burn Rate."

The Cash Burn Rate for early-stage companies measures their financial heartbeat. Startups can go months and even years without revenues (much less profits) so measuring and managing cash burn is a major chore for the management team of such firms. For most larger organizations that have generated revenues and profits for years, this concept of reporting "Zero Revenue Solvency Rate" would have been incomprehensible only a few months ago.

\section{The Hypothetical Example - Wisco Electric}

Wisco Electric (WE), a hypothetical company, developed analytical instruments including electron microscopes for customers in the semiconductor industries, research labs at higher education institutions, and firms in the biotechnology space. WE originated in Wisconsin in late 2005 and scaled its business manufacturing, selling microscopes at upwards of $\$ 2$ million with gross margins as high as $70 \%$. Prior to 2017 , WE's business model generated nice profitability on growing revenues, as shown in their financial statements in the Appendix. In this article, the WE results and future projections will be used to illustrate the application of the Zero Revenue Solvency Rate (ZRSR). It will utilize the 2017 and 2018 projections of WE's financial plan to apply the concepts.

\section{What is the Cash Burn Rate? How is it Measured?}

The ZRSR is corollary to the Cash Burn Rate, the amount of cash an organization loses on a periodic basis. Investors and managers associated with earlystage firms utilize the Burn Rate especially in prerevenue phases to closely measure and manage the cash flow of a firm. How does one calculate the Burn Rate? Investopedia defines the Cash Burn Rate as: "the rate at which a company spends its supply of cash over time. It's the rate of negative cash flow usually quoted as a monthly rate." ${ }^{\text {[1] }}$ In my entrepreneurship classes I measure Burn Rate using the following Formula:

Burn Rate $=$ Free Cash Flow before External Financing $^{[2]} /$ Number of Days during Free Cash Flow Period

Typically, burn rate is calculated on a daily, weekly or monthly basis to ascertain how long the firm's cash balance will last (i.e, Time-to-Cliff). While most associated with startups, the Cash Burn measurement can also be applied to mature firms that generate revenue, profits, and/or cash flow. For example, WE, the analytical instrument company, projected its cash flow for a two-year period of 2017 and 2018 as part of its annual planning process. In this example, WE was expecting a decline in revenue due to the loss of customers and other market conditions. Thus, 2017 and 2018 were not expected to be favorable years for the company.

(Note: Most organizations prepare the financial statements under the "accrual method of accounting." 
For a more detailed explanation of accrual accounting and the differences between cash and accrual methods of accounting, visit

https://www.investopedia.com/terms/a/accrualaccountin g.asp).

The projected years are as follows:

Wisco Electric Company - Projected Cash Flow Summary. In \$000's.

\section{$2017 \quad 2018$}

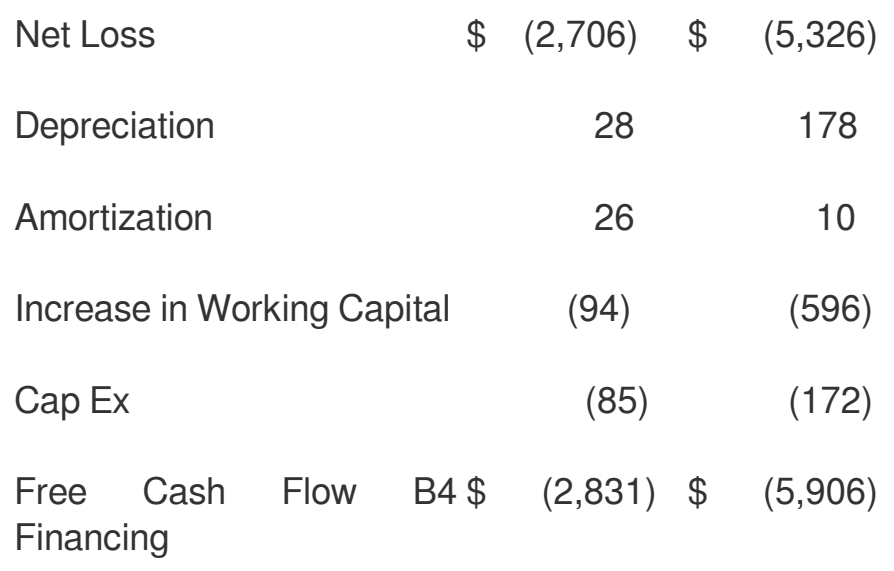

The daily Burn Rate for both years were $\$$ (7.8 thousand) in 2017 and $\$$ (16.2 thousand) in 2018, respectively. (See Table 2)

\section{7}

2018

$\begin{aligned} & \text { Annual } \\ & \text { Cash Flow }\end{aligned}$
Free $\$(2,831) \quad \$(5,906)$

Divided by:

365 days/year 365 Days 365 Days

Daily Burn Rate $\$(7.8 /$ Day $) \quad \$(16.2 /$ Day $)$

At the beginning of 2018, the company projected a cash balance of $\$ 37$ thousand before obtaining any financing. Thus, the company expected its cash balance to last just over five days if no steps were taken. In this planning period, WE was planning a decline in the business, but certainly not to the extent of a pandemic like the world experienced in 2020 and 2021. Under even harsher business conditions like a pandemic, what might WE's financial condition have looked like? What are some steps they could have taken to reduce the risk to the firm? The Zero Revenue Solvency Rate (ZRSR) analysis can help answer such questions.

\section{Zero Revenue Solvency Rate}

The Zero Revenue Solvency Rate for large companies (mentioned in the podcast) attempts to measure how long a larger company's cash will last if revenues become zero over an extended period of time. This is a worst-case scenario similar to what many firms have experienced during the recent pandemic. Such information to management and a board of directors gives them a starting point in determining action steps needed if the inevitable happens.

Using the Wisco Electronics example, the firm's income statement and balance sheet suggested a relatively strong financial condition at the end of each calendar year (Income Statement and Balance Sheet, as shown in the Appendix in this article). The company possessed $\$ 8.015$ million in cash at the end of 2016 following a year of strong revenues at $\$ 423.4$ Million and consistent profits of $\$ 13.229$ Million.

The cash flow from operations before external financing (Note: I exclude Current Notes Payable as part of Current liabilities, as negotiations with lenders can extend payment terms) shows that even at a strong revenue level in 2016 WE, Free Cash Flow before External Financing is $\$$ (15.457 Million).
Net Income (Loss)

Add: Depreciation
2016

(In

thousands)

$\$ \quad 13,229$

$\$ \quad 7,700$ 
Change In Current Assets (Ex Cash) \$ $\quad$ (49,644)

Change in Current \$ 14,494

Liabilities

Cap Ex and Other Assets

Free Cash Flow B4 Ext

$\$(15,457)$ Fin

Using that as the drain of cash, the burn rate for Wisco would approximate:

Free Cash Flow Before $\$(15,457)$

External

Financing

Divide by:

\# of Days in the Year 365 Days

Daily Burn Rate \$42.3K/Day

The company's Time to Cliff based at the end of 2016 is:
Cash on Hand $-\$ 8.01$ Million
$12 / 31 / 2016$

Divide By:

Daily Burn Rate

\$42.3K/Day

Days of Cash Left

189 Days

While WE showed a profit for 2016, a significant amount of cash was being used in net working capital, or broad increases in the amount of accounts receivable and inventory that the company possessed.

For an organization the size of Wisco, a runway of over 6 months during "normal" times is probably adequate since they can adjust working capital, put off capital expenditures, obtain greater external financing from banks and investors, and take other measures. If management expects the trend to continue into 2017 based on lower sales, how would WE be affected in that year and beyond if an event like Covid-19 occurred? What happens if the firm's sales decline to extremely low levels in a short amount of time? The Zero Revenue Solvency Rate is the most extreme, conservative financial stress scenario a firm can develop to plan for such an event.

\section{Developing the Zero Revenue Solvency Rate}

There are a series of steps to developing the Zero Burn metric, including an examination of the company cost structure that identifies cost behavior:

1. Identify cost categories that Variable, Fixed and Mixed in their relation to Revenue generation.

2. Attempt to identify the portion of Mixed Costs that is variable and fixed in nature. If this too timeconsuming, lump Mixed Costs into the Fixed Category.

3. Identify total Variable and Fixed Costs.

4. Calculate Free Cash Flow before External Financing at Zero Revenues using the traditional formula.

5. Estimate the Zero Revenue Solvency Burn Rate.

6. Determine the Time-to-Cliff in days -- how many days of cash are left without obtaining financing or taking other drastic steps.

Variable costs vary based on the amount of output produced. Variable costs may include labor, commissions and raw materials. Fixed costs remain the same regardless of production output. Fixed costs may include lease and rental payments, insurance, and interest payments. 
Example 1 - Fixed vs. Variable Costs. The following table shows various costs incurred by a manufacturing company:

$\begin{array}{lll}\text { Cost } & \text { Variable } & \text { Fixe } \\ \text { Depreciation of } & \mathrm{x} \\ \text { executive jet } & & \end{array}$

Cost of shippingx

finished goods to

customers

Wood used inx manufacturing

furniture

Sales manager's

salary

Electricity used inx

manufacturing

furniture

Packing suppliesx

for shipping

products

Supervisor's

salary

Advertising costs

Executive's life

insurance

Let's say that $A B C$ Company manufactures buses and it costs the company $\$ 250$ to make one seat. In order to run its business, the company incurs $\$ 550,000$ in rental fees for its factory space. Let's take a closer look at the company's costs depending on its level of production.

Fixed

$\begin{array}{llll}1 & \$ 250 & \$ 250 & \$ 550,000 \\ 1000 & \$ 250 & \$ 250,000 & \$ 550,000 \\ 1500 & \$ 250 & \$ 375,000 & \$ 550,000\end{array}$

As $A B C$ produces more buses, note that the cost per seat stays the same but the total variable cost increases directly with the number produced. Fixed costs, on the other hand, stay the same with a range of production (i.e., if the firm needed to add machines or a new facility, then overall fixed costs would increase) not changing as the number of buses produced increases or decreases. In most businesses, the Cost of Goods Sold and commissions or other ad-related expenditures (i.e., incurred based on a "percent of sales") are considered "variable costs." A majority of operating expenses including salaries, benefits, insurance, etc., would be lumped into the fixed expense category. Any expense that is a combo of variable and fixed or a mixed cost behavior (like television ads that you know generate sales but can't specifically identify its correlation with revenue) would be in this category.

In Wisco's case, we'll simply lump the mixed costs with fixed. In reality, cost accountants or other analysts in a firm would analyze the cost components of mixed costs using regression techniques or other statistical methods to calculate the mixed costs at different sales levels, noting the degree of change of the costs (in \$000's).
Variable

Cost of Goods Sold $\quad 285,064$

$\begin{array}{llll}\text { Number of } & \text { Variable } & \text { Total } & \text { Total Fixed } \\ \text { Buses } & \text { Cost per } & \text { Variable } & \text { Cost } \\ \text { Produced } & \text { Seat } & \text { Cost } & \end{array}$

Fixed (including any
Mixed)

Selling, Gen and Admin 95,048 
Depreciation $\quad 7,700$

\section{Research and8,039 \\ Development}

Interest Expense

6,333

Total Fixed Costs

117,120

Now that the fixed costs have been identified, a Zero Burn Rate can be calculated. For Wisco, the Zero Revenue Solvency Rate at the end of 2016 is approximately $\$$ (271.1 thousand/day).

(In \$Thousands)

\section{6}

Net Loss $=$ Fixed Costs $\$(70,272)$

$x(1-\operatorname{tax}$ rate of $40 \%)$

Add: Depreciation7,700

Expense

Change in Current $(49,644)$

Assets (Ex Cash)

Change in Current14,494

Liabilities

Change in Fixed Assets(1,236)

and Other Non-Current

Assets

Free Cash Flow B4 $(98,958)$

External Financing

Divide by:

\# Days in the Year 365 days

Daily Cash Burn Rate $\$(271.1) /$ day
Cash on Hand $-\$ 8,015$

$12 / 31 / 2016$

Divide By:

Daily Burn Rate \$271.1/Day
Zero Revenue Solvency30 Days
Rate

Assuming Zero Revenue, with no changes in other financial variables, Wisco's Cash will roughly last 30 days. Management and board members would then discuss what they might do if the revenue stops to extend the improve the Zero Revenue Solvency Rate.

\section{Next Steps}

Again, this is the worst-case scenario, or what some call the "Break-the-Glass" scenario (where the very worst happens and the glass case needs to be broken to get to the extinguisher to put out the blaze). Because such a scenario - declining to zero revenues overnight - was thought to have such a small probability of happening, most firms didn't anticipate it. However, now that the Covid-19 outbreak has caused such an occurrence, organizations of all sizes must now calculate it to evaluate the impact on the firm.

So, in the case of Wisco Electronics, knowing that if such an event came to fruition, what might they do? A good place to start is to examine the components of Free Cash Flow before seeking financing.

What is the Zero Revenue Solvency Rate the company should be targeting? The first step is to set a target rate -- or how many days of cash the firm would need to survive a complete shutdown of business where revenues quickly decline to zero and may stay there for a long time. In the early stage world, having 12 months or more of cash on hand is considered adequate for most firms that don't have sources of revenue. For larger firms with revenue, a shorter period may be desirable with the goal of having access to external 
capital if needed.

Net Income (Loss) : Pretty self-explanatory. In an environment where revenue declines as much as a $100 \%$ in a short amount of time, fixed and mixed costs have to be cut to assist cash flow. However, management must balance the cutting of excess vs. muscle. Mass layoffs may be necessary but should be avoided or minimized as much as possible. Furloughs or salary cuts without terminating people can be a good alternative to dramatic workforce reductions.

Depreciation and Amortization: Not a lot one can do here except possibly maximizing depreciation expense using the tax code that may lower taxes and potentially more income/cash flow. However, this is a difficult strategy to get immediate effect.

Working Capital: Current assets, other than cash, must be reduced to increase cash flow. Some questions to ask:

- Can accounts receivable invoices be "factored?" (i.e., a financial transaction in which a company sells its receivables to a financing company at a discount).

- Can more sales be switched to credit card sales (weight the discount vs. the improvement in cash)?

- Can any discounts be provided to speed payments on account? Can late receivables be incentivized to pay?

- Any older inventory that can be sold off, even at a discount?

- Can accounts payable be stretched? (defer later).

- Any short-term debt that is due, can it be deferred?

- Can tax payments be deferred?

Capital Expenditures - Can they be deferred? Can they be leased to avoid a large down payment? If the policy is to pay the entire amount - can the firm buy over time (at least for this short-term need)?

- Once all operational and internal sources for capital have been exhausted under the Zero Revenue scenario, then external sources must be identified.

- Does the firm have access to a line of credit or other short-term loans at relatively low interest rates?

- Are their equity markets or investors that can be 'tapped' for short-term financing?

- Can the firm re-negotiate current loans or other investments to lessen the short-term pressure on cash flow?

\section{Conclusion}

The Zero Revenue Solvency rate is becoming a critical ratio that many board members, investors, suppliers and other stakeholders will ask about. Traditionally a staple of the startup world, it now applies to organizations of all sizes and levels of success to provide an idea of the cushion available when the scenario that could never happens does happen.

[1 https://www.investopedia.com/articles/fundamental/0 4/022504.asp

[2] Free Cash Flow B4 External Financing = Net Income (Loss) for the Period + Non-cash expenses (such as Depreciation or Amortization) - Increase in Net Working Capital - Capital Expenditures. 